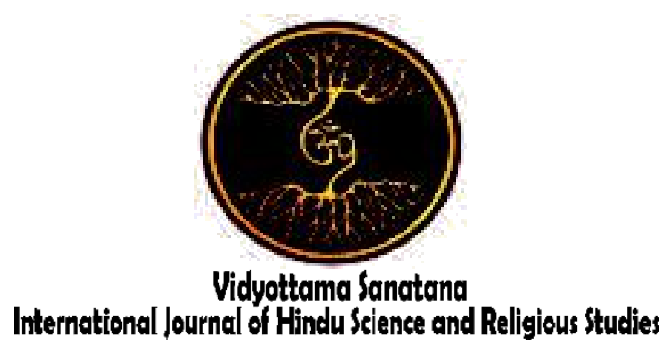

Vol. 2 No. 1 May 2018

\title{
Theme, Message, and Hindu Ethics Teaching in Gaguritan Cangak
}

\author{
By: \\ I Wayan Lali Yogantara \\ Institut Hindu Dharma Negeri Denpasar \\ E-mail: lali_yogantara@ihdn.ac.id
}

Received: January 22, 2017

Accepted: May 5, 2018

Published: May 31, 2018

\begin{abstract}
Gaguritan Cangak is classified as a classic literature that can be studied in terms of themes, messages, and teachings contained in it. The Gaguritan Cangak theme is the impact of good and bad deeds, the message delivered does not quickly believe to the promises or sayings of others, always be wary of self-salvation, and believe in the truth of karmaphala law. The Hindu ethic in Gaguritan Cangak emphasizes the teachings of karmaphala, that any good deeds will be good deeds and bad deeds will be bad. The doctrine of good deeds of human deeds is known by the teachings of Trikaya Parisudha and Tri Mala.
\end{abstract}

Keywords: Theme, Message, Hindu Ethics, and Gagururitan Cangak

\section{Introduction}

Literature including gaguritan generally contributes knowledge about various solutions to solve various problems of life in order to be more meaningful. According to Esten (1978: 8), through literary inventiveness, a writer is able to show higher value, and interpret the meaning as well as the nature of life.
Gaguritan is "a work of traditional literature (classical) that has a certain system of certain literary conventions" (Agastia, 1980: 16). While Granoka (1982: 2) argues that a literature like gaguritan, in addition to the elements of its formation, can also be examined from the content contained. In connection with the statement, then a gaguritan contains content. The contents are meaning, message, or idea that the author 
wants to convey to the reader. Submission of these messages aims for the reader can take the positive meaning contained in the literature, especially gaguritan, so it can be used as a guide in living life.

In Bali, there are many kinds of gaguritan, some of them contain a message or teachings of Hindu ethics. Gaguritan Cangak is one of gaguritan containing the message or teachings of Hindu ethics. Gaguritan Cangak includes fable (a story that tells the life of animals that behave like humans). Fable is a fictional story, a mere fantasy.

Gaguritan Cangak is probably taken from Tantri Kamandaka, including the group of Panca Tantra stories originating from India. The story is spread in Indonesia, also in other countries. In Bali, this story is very popular because its didactic nature contains high moral education. In the book Tantri Kamandaka (Nandhaka Harana) published by Paramita Surabaya, there is a statement from the Head of Service P and K Prop. Bali in 1986 that the story of Tantri is taken from the lontar of I Nyoman Kusuma, Tampwagan Amlapura. Because in the last part of the hymn, it was mentioned: ksantawayakna gatining kawya apunggung milwa nuda prapancaning rasa tunggal, which is candra sengkala, as the time this hymn was composed, ie 1650 Śaka (1728 AD). It was stated that the Dyah Tantri Carita song mentioned above was prepared by Padanda Nyoman Pidada and Padanda Ketut Pidada in 1728 AD (Tim Penyusun, 2005: ii-iii).

The story of Cangak is one of a number of stories contained in Tantri Kamandaka (Nandhaka Harana). This is contained in the lontar from pages 121 a to 133 b. The story contained in Gaguritan
Cangak is in conformity with that contained in Tantri Kamandaka mentioned above.

It hasn't been known yet, that the writer of Gaguritan Cangak took the source from Tantri Kamandaka, because of no one mention that it has taken the source of Tantri Kamandaka. Gaguritan Cangak was written in lontar by Made Pasek in the Caka year 1912, 184 years after Tantri Kamandaka was written, that was the Caka year 1723.

Gaguritan Cangak is classified as a classic type of literature that can be studied in terms of structure and values or teachings contained in it. In this case, this study was limited to themes, and messages (elements of structure) and the teachings of Hindu ethics. The gaguritan was very worthy to be studied from the aspects of Hindu structure and ethics because it is a literary work and tells the character of a heron (Cangak) whose character is very cunning full of tricks and justifies any means to achieve the desired goal. What is interesting and intriguing is that the crane is likened to a Padanda (Hindu holy man) better known as Padanda Baka, pretending to save the fish from a pond, but in fact, he is full of tricks, outsmarting the herd of fish it wants to be moved to further prey.

Although it tells the story of animals (birds and fish) that disbelieve in the promise (mithya discourse), especially those done by Padanda Baka, it contains a moral message for the benefit of mankind in fostering and improving ethics or morals.

\section{Methods}

The research used the hermeneutic method. This was done to understand religion as well as literary works, with the consideration that among the papers, the closest to religion is the work of literature. At 
some stage, the religious text is the same as the literary work (Kutha Ratna, 2011: 45). The approach used is a mitopoik approach that incorporates elements of religion and art.

\section{Discussion}

\subsection{Gaguritan Cangak Synopsis}

Gaguritan Cangak synopsis can be described as follows. There was a Cangak or a crane who was thinking to be able to get and eat the fish that lived in a lake. The cunning, evil crane pretended to be good and stops eating fish. This attitude was shown to a set of fish to be benign and to believe that he had become good.

One day, Cangak stood on the edge of the lake, dressed in white, wore a crown on his head, stretching like a Padanda or a saint. To the herd of fish, he pretended to have repented, became a saint, and no longer killed including preying on fish. This was done because he was once severely dying. He said that his illness was caused by his bad behavior. According to the word of God, the pain could be healed as long as he stopped doing evil, and purified himself, tried to be a saint and did good things. It has been obeyed, then apparently the pain heal instantly.

His tricks worked. The herd of fish believed in the crane's words. Therefore Cangak was very happy, he planned to take the fish and brought it to the middle of the forest and ate it there. He told all the fish that soon the lake of the fish would be destroyed and all the fish would be caught. Cangak then pretended to be good and ready to help the fish to move to another place, ie in a pond that was in a very secret forest place.

Almost all fish believed in the Cangak's crap. The fishes pleaded for help to be saved from the dead. There's only one creature which doubt Cangak's words, that was the Crab. So when the fish are ready to move to a place that has been planned by the Cangak, that was on a mountain, it turned out the crab to be silent. One by one the fish were brought flying to a mountain, on a flat rock. That's where the fish were eaten.

When the fish were running out, which was still only the crab, then the crab's turn would be brought flying. The crab then moved, the neck of Cangak gripped with its hands. It turned out that the suspicion of the Crab proved, that the Cangak still remain evil, he has consumed his friends. The Crab saw fish bones piled on a flat rock. He was very angry, so his hands was clenched more firmly on the Cangak's neck. The Crab threatened to kill for the crimes that Cangak had committed. The Cangak which gets threats like that was very scared. So, he asked the Crab to forgive him, so as not to be killed and promised to be ready to serve his life for the Crab.

The Crab does not care about Cangak's request. Instead, he was told to quickly bring the Crab back to its original place. Upon arrival at the lake where the Crab lived, Crab said that it does not merit to forgive a Cangak which had done evil except to gave the death penalty. Her skull was tightly clasped until she broke the Cangak's neck. The Cangak died from the results of his evil deeds.

\subsection{The Theme and Message uf Gaguritan Cangak}

The theme is the basic idea of the story used as the starting point of the author in composing a literary work. Gaguritan Cangak raised the theme of Karmaphala (the impact of good and bad deeds). The concept of karmaphala in the teachings of Hinduism 
is about the truth of the consequences arising from an act that has been done. If good deeds are done (subha karma), then good results will also the same, but if bad deeds (aśubha karma) are done then it will have bad results.

Gaguritan Cangak tells the story of Cangak's ruse to deceive a flock of fish, to kill him later and eat. As a result of his evil deeds, then the Cangak was finally killed by the Crab. The killing of Cangak can be seen in the following statement of Pupuh Ginada.

Sajaba cai bangkaang, tan paguna $\mathrm{nu}$ maūrip, saidupan ngae cāra, ne karmman caine pupu, ala ayu mūla mabwah, tur kakapit, pégat bawong ya I Cangak (Kantor Dokumentasi Budaya Bali, 1995: 9).

The meaning:

Unless you are killed, useless is alive, you have a lifetime of trouble, this is the result of your deeds, good and bad is fruitful, and grasped, cut off the neck of I Cangak.

Based on the above quotation, it can be understood that the theme of Gaguritan Cangak is about Karmaphala, which illustrates that the Cangak who always do evil, then the result was death.

The message is the moral message the author wishes to convey to the reader through the behavior of the characters and the storyline in accordance with the author's view.

In Gaguritan Cangak, there are some messages submitted by the author to the reader, such as:

1) We must not believe in the promises or sayings of others. The example of this is that the fish are foolish and quickly believe in the words of the Cangak, they end up hurt.
2) Always be aware of your personal safety. It is depicted on the Crab's vigilance, he is not easily fooled, he finally survived.

3) Believing in the truth of the law of karma (karmaphala). It is depicted on the Cangak's evil actions, in the end, he met his death as a result of his evil. Even in ending, Gaguritan Cangak's writings are reaffirmed about the quality of an act, as stated in the following Pupuh Ginada.

Amonto bapa ñatwayang, céning bisa maminéhin, karana céning suba tatas, śubha aśubha karmma tau, Bapa twara ja mangajah, twah pakeling, sutakerthin bapā ken panak (Kantor Dokumentasi Budaya Bali,1995: 9).

The meaning:

Fathers say, children can think, because children are clear, subha asubha karma are known, Dad does not teach, just remind, father duty to the child.

According to the above quotation, it is implicitly conceived that everyone should always understand the quality of karma in this gaguritan is called "subha asubha karma". In addition to understand it, it is certainly expected to avoid asubha karma and instead does subha karma, because according to the law of karma that subha karma (good deeds) is appropriate for the good and the salvation of life.

\subsection{Hinduism Ethics in Gaguritan Cangak 1. Hinduism Ethics}

In Hindu social life, ethics is often referred to by the term morality. Mantra (1993: 5) in his book entitled Tata Susila Hindu Dharma, explains that ethics means good and noble behavioral rules which should 
be the guidelines of human life. Vedas are an early source of ethics. As a holy book, the Vedas are a source of Hindu teachings, because, from Vedas, it flows teachings that teach the truth of Hinduism. In the context of Hindu ethics, the Vedas guide the actions of mankind throughout their lives. Vedic leads an individual life as well as social life, nation, and state (Titib, 1996: 19-20).

Furthermore, it is said that the ethical teachings of Hindu or ethical behavior are a good and true behavior for the happiness of life and harmony of human relationships with Hyang Widhi, between human beings, humans with the universe and his creation. Hindu ethical teachings cover a very wide range of areas including truth, nonviolence, virtue, generosity, noble virtue, purity of heart, and morality (Titib 1996: 308).

There are several types of ethical teachings (Hindu ethics) that should be understood and guided in guiding daily life behaviors such as Tri Kaya Parisudha and Tri Mala. Tri Kaya Parisudha means three noble deeds (good). With regard to it, Sura (1985: 94-99) states that Tri means three, Kaya means movement/body and Parisudha means holy. So Tri Kaya Parisudha is three purified gestures. The first Kayika Parisudha can be formulated as any behavior associated with a purified body. Furthermore, the second Wacika Parisudha is said to be right and good to be called the Wacika Parisudha. Almost everyone speaks, speaks to convey his heart to others. Thirdly, Manacika Parisudha is a good and holy mind. Tri Kaya Parisudha can be used as a guide to live and be implemented in everyday life. Because thoughts, words, and deeds can make a person into a good one and fall into a bad one, and therefore, should be able to control it and lead to a good way to gain a harmonious and a peaceful life.

Tri Mala means three actions that are not good if implemented, they are: (1) Moha, (2) Mala, and (3) Kasmala. Moha means mind, bad feeling such as cheating and arrogance. This is in contrast to Manacika Parisudha in the teachings of the Tri Kaya Parisudha. Mala means words, bad talk, like lying and dirty. Mala is the opposite of Wacika Parisudha in Tri Kaya Parisudha. While Kasmala means bad deeds, such as abject deeds and various other forms of crime. This is contrary to Kayika Parisudha in the teachings of the Tri Kaya Parisudha (Tim Penyusun, 1986: 18). Hinduism indicates the existence of three kinds of bad deeds called Tri Mala which should be avoided by every Hindu and advocated to do good deeds (Tri Kaya Parisudha).

In common life, people need rules of conduct. It is not right for everyone to do as they please, but to obey the prescribed rules of life. Hindu ethics as a behavioral rule plays an important role. Hindu ethics aims to foster harmonious relationships between a person and the living beings, a harmonious relationship between the family that forms the society, between one nation and another and between humans and the natural surroundings. A harmonious relationship between a person and his neighbor, between a member of a society, a nation, leads a safe and secure life. A harmonious and secure relationship ensures happiness in this life (Mantra, 1993: 5).

Hindu ethics or moral order foster human nature to become members of the family, members of society, and citizens of noble personality, for the realization of happiness. This doctrine also leads human to 
harmonize himself with his fellowman and leads to the unity of his Jiwatman (spirit) with Paramatma (Hyang Widhi or Brahman).

Gaguritan Cangak is a fable that is a story that describes the character and the human mind that the perpetrator is played by the animal, contains moral education and character. The Cangak is the main character in the gaguritan. The human character that is contrary to the ethical and moral values depicted by the character of Cangak.

Despite Cangak's good, helpful, temperament, it is actually a good pretense, but it is actually a form of lie and deceit. Therefore, Cangak's story is made possible as an allusion to a man of evil character but good pretense. When observed carefully, that Gaguritan Cangak contains the teachings of Trikaya Parisudha and Tri Mala.

\section{The Teachings of Trikaya Parisudha and}

\section{Tri Mala in Gaguritan Cangak}

\section{1) Manacika Parisudha and Moha}

The teachings of Manacika Parisudha and Moha are indicated by the characterization of Cangak. Cangak's character always thinks and makes sense to deceive the fish, so that all fish become tame, easily caught, killed and eaten. This can be seen in the following Pupuh Ginada.

Ngawit bapa manuturang, I Cangak sédék minéhin, kenken jani ban madāya, bene apang bakat éjuk, di télagane apang télah, sékabédik, sadina awake ngamah.

Mélah jani upayaang, jani ngamah malu tunain, ngalih di tongose lenan, bene apang tusing tau, alusin malu ya baan, sékabédik, mūști ya sayan tabah.
Yening suba boh makéjang, gampang

jani bān ngéjukin, pépéd ya

sékabédikang, kébérang johang

mundut, ditu mara lawut tadah,

kéñir-kéñir,

I Cangak pragat ngeka dāya (Kantor

Dokumentasi Budaya Bali,1995:1-2).

The meaning:

Father began to tell, I Cangak was thinking, how is the reason, the fish to be caught, in the lake to run out, every day will be eaten.

The good now strives, now eat first reduced, looking elsewhere, the fish do not know, invited to make their first, surely they are tamer.

If they are all tame, it's easy now to catch him, grab him bit by bit, flown away, there eaten, smiling, I Cangak finished making effort.

Based on the above quotation, it can be understood that Gaguritan Cangak contains the teachings of Moha, which is not good thoughts, deceptive thinking of pretending well to the fish to be docile, easy to catch, then killed and eaten. By pointing at the evil mind then resulted in death to the Cangak. If this story is related to the human character who always thinks evil (Moha), then it is not good for his survival, this story explicitly teaches to avoid evil thinking and good thinking (Manacika Parisudha).

\section{2) Wacika Parisudha and Mala}

Gaguritan Cangak contains the teachings of Wacika Parisudha and Mala. These are indicated by the attitude of the Cangak who said lies, deceiving swarms of fish in the pond. The form of deceit or lie appears in the following Pupuh Sinom. 
Ne malu maan sakit raat, dasdasan bapa mati, ngarengreng téken kaahkaah, angkyan bapa nu abédik, gantin bapa nu maurip, Bhațāra asung manulung, maśabda saking māntara, mapiccha ubad dahat sulit, apang suwud, Bapa ñalanang hingsakamma. Di suban bapa ngiringang, Bapa ségér pramangkin, tan paboreh tan paubad, di subane ségér jani, Bapa bwin kandikain, maprayaścita mapupug, mawintén térus madhikșā, nganūtin śasana śuci, ñalanang mādan kadharmman.

Bapa tusing bani tulak, téken pawisik Sanghyang Widhi, jani suba bapa ñalanang, suwud mangsa mamātimati. dadi padānda mraga śuci, dosan bapa ane malu, tébus bapa apang télah, éda takut céning jani, mai mapunduh, ngajak bapa mapénéman.

Sang Bhaka kéñém di manah, reh dāyane mangambahin, bene tusing ada réngas, pada mélér panésékin, I Cangak mañambungin, prajani ngésehin sému, mamuñi ngarod mégat-mégat, uduh panak bapa céning, twara buwung, Céning enggal kerusakan.

Sédih bapa tan pahingan, reh lékéte téken céning, Bapa suba pédas pésan, orthane ya suba paști, méndega péñcar lan pañcing jaring, tukang

sugsug lan sawu, lakar tékā mangubékang, di saśih kapate jani, twara buwung, céning oña kabakatang (Kantor Dokumentasi Budaya Bali,1995: 3-4).

The meaning:
When it used to be very ill, almost father died, ngarengreng and kaah$k a a h$, father's breath is only a little, the fate of father is still alive, Bhatara will help, said from the sky, giving medicine is very difficult, to stop, you do himsakarma.

After you obey, you heal instantly, without param without drugs, after healthy now, father again told, maprayascita mapupug, mawinten continues to examine, according to the behavior of the saint, to run the socalled truth.

Father did not dare to refuse, to whisper of Sang Hyang Widhi now father has done, stop eating meat, So Padanda as a saint, the sin of the father of the foregoing, Father ransom to run out, does not be afraid now, come here together, talk with the father.

The Bhaka smiles, because the trickery is successful, the fish are not wild, are approaching each other, I Cangak connect, instantly fixing the face, saying ngarod stammered, uduh my child is silent, not void, Ananda quickly destroyed.

Father sad, because closely with ananda, father is very clear, the news is certain, the scatter bolt and the fishing nets, the sugsug and sawu, will come stirring the water, at the present of sasih kapat, not void, Ananda all got.

Based on the above quotation, it can be asserted that the Cangak has said a lie, pretending to be a saint, not committing murder and saying scaring the fish. These evil words in the teaching of Tri Mala include Mala. 
If associated with the behavior of a man who likes to lie, pretend to be a saint, it is clear that the person concerned has sinned. Therefore, by pointing to the example of evil words such as deceit that ultimately result in death, it has indirectly advocated avoiding it, and instead said the truthful, and good (Wacika Parisudha). There is something interesting in the illustration of Cangak's depiction. He is depicted as a saint, dressed in all white, complete with a set of attributes of kasulinggihan and is called Padanda or Maharsi. If analyzed naturally, there are many cranes whose feathers are white and prey on fish. But if this is an allusion or social control, then if there are people who pretend good and wise but actually they are criminals, then deserve to be called Padanda Bhaka.

\section{3) Kayika Parisudha and Kasmala}

The teachings on Kayika Parisudha and Kasmala in Gaguritan Cangak can be seen in the following Pupuh Ginada.

Sarāhina kagilirang, Sang Cangak kéndél mangikgik, mokoh sadinā mangamah, kaéjohang maring gunung, di duwur batune asah, ngae silib, ane nu pang dāya nawang (Kantor Dokumentasi Budaya Bali,1995: 6).

The meaning:

Every day rotates, The Cangak loves mangikgik, fat every day eating, kept away on a mountain, on a flat stone, made secret, who is still unknown.

The above quote has illustrated that the deed of Cangak's deceit is that he can daily bring a fish to a mountain and eat it there. This act is classified as Kasmala which contradicts Kayika Parisudha's teachings. By depictions of evil deeds (Kasmala) that are unfavorable to the culprit, then everyone is not worthy to imitate the evil deeds but instead is directed to good deeds (Kayika Parisudha).

It can be asserted that Gaguritan Cangak loaded with contents about the ethical teachings of Hindu that will be conveyed to the reader of the text when reading and to the listener when sung, the teachings of Trikaya Parisudha and Tri Mala. The teachings of Trikaya Parisudha are a doctrine concerning good and bad of human behavior. Trikaya Parisudha's teachings always lead people to behave well and avoid bad behaviors. With the portrayal of character and behavior of the main character of the story of the Cangak in Gaguritan Cangak, the composer of literature wanted to convey a moral or ethical message that people who behave bad or evil must have an impact on unworthiness. With the consequences of unlawfulness caused by the evil act, actually, the composers intend that readers and listeners can avoid the behavior of Tri Mala (three bad behaviors).

Hindu ethical teachings in Gaguritan Cangak are still relevant to be guided in fostering and developing the character of today's generation so as not to be hypocritical, egotistical, cunning, and greedy. In order to every good personality, virtuous noble character, integrity, do not give priority to self-interest or group. It also guides people against arbitrariness and does not like to take the rights of others unlawfully. If the teachings of Tri Kaya Parisudha be the foundation of every person's behavior, it will undoubtedly be able to foster the harmonization of life, so able to move quietly and comfortably, and can realize the purpose of life. 


\section{Conclusion}

First, the theme of Gaguritan Cangak is about the effects of good and bad deeds, the message is not to be quick to believe in the promises or sayings of others, to be always aware of the safety of the self, and to believe in the truth of karmaphala law.

Secondly, the Hindu ethical teachings in Gaguritan Cangak emphasize the teachings of karmaphala, that any good deeds will be good deeds and bad deeds will be bad. Both the bad deeds of humans are known by the teachings of Trikaya Parisudha and Tri Mala. Trikaya Parisudha teaches to think good (Manacika Parisudha), speaks good (Wacika Parisudha) and behaves well (Kayika Parisudha) and avoids thinking evil (Moha), saying bad (Mala), and doing bad (Kasala).

\section{References}

Agastia, IBG. 1980. Geguritan Sebuah Bentuk Karya Sastra. Makalah disampaikan dalam Sarasehan Sastra Daerah Pesta Kesenian Bali ke-2 di Denpasar.

Atmaja, I Made Nada, Dkk. 2010. Etika Hindu. Surabaya: Paramita.

Bagchi, S. S. (2017). The Great Betrayal: Potential Statelessness After Living Decades In Mother India. Vidyottama Sanatana: International Journal of Hindu Science and Religious Studies, 1(2), 122-131.

Esten, Mursal. 1978. Kesusatraan: Pengantar Teori dan Sejarah. Bandung: Angkasa.

Granoka, Ida Wayan Oka. 1982. DasarDasar Analisis Bentuk Sastra Paletan Tembang. Denpasar: Fakultas Sastra Universitas Udayana.
Kadjeng, I Nyoman, Dkk (Penerjemah). 2009. Sarasamuccaya. Surabaya: Paramita.

Kantor Dokumentasi Budaya Bali. 1995. Gaguritan Cangak. Denpasar: Pemerintah Propinsi Daerah Tingkat I Bali.

Kutha Ratna, Nyoman. 2007. Sastra dan Cultural Studies Representasi Fiksi dan Fakta. Yogyakarta: Pustaka Pelajar.

Kutha Ratna, Nyoman. 2011. Teori, Metode, dan Teknik Penelitian Sastra. Yogyakarta: Pustaka Pelajar.

Mantra, Ida Bagus. 1993. Tata Susila Hindu Dharma. Jakarta: Hanuman Sakti.

Mantra (Penerjemah). 2000. Bhagawadgita. Denpasar: Pemerintah Propinsi Bali.

Punyatmadja, I.B. Oka. 1984. Ślakrama. Denpasar: Pemda Tingkat I Bali Proyek Penyuluhan dan Penerbitan Buku Agama.

Suastika, I. M., Jirnaya, I. K., Sukersa, I. W., \& Puspawati, L. P. (2017). The Process Of Transforming The Mahabharata Literary Work Written In The Old Javanese Into Geguritan Sarpayajnya And Geguritan Kicaka Written In The Balinese Language. Vidyottama Sanatana: International Journal of Hindu Science and Religious Studies, 1(2), 103-114.

Sudarsana, I. K. (2016). DEVELOPMENT MODEL OF PASRAMAN KILAT LEARNING TO IMPROVE THE SPIRITUAL VALUES OF HINDU YOUTH. Jurnal Ilmiah Peuradeun, 4(2), 217-230.

Sudharta, Tjok. 2009. Ślokantara Untaian Ajaran Etika. Surabaya: Paramita.

Sura, I Gede. 1985. Pengendalian Diri dan Etika. Jakarta: Hanuman Sakti. 
Teeuw, A. 1984. Sastra dan Ilmu Sastra. Jakarta: Pustaka Jaya.

Tim Penyusun. 1986. Pelajaran Agama Hindu. Jakarta: Yayasan Wisma Karma.

Tim Penyusun. 2005. Tantri Kamandaka (Nandhaka Harana), Surabaya: Paramita.

Tinggen. 1994. Aneka Sari Gending-Gending Bali. Singaraja: Rhika Dewata.

Titib, I Made. 1996. Veda Sabda Suci Pedoman Praktis Kehidupan. Surabaya: Paramita. 